\title{
Evaluation of Mechanical Alloying to obtain Cu-Al-Nb Shape Memory Alloy
}

\author{
Maria do Carmo Amorim da Silva ${ }^{\mathrm{a} *}$, Severino Jackson Guedes de Lima ${ }^{\mathrm{b}}$ \\ a'Departamento de Metalurgia e Materiais, Escola Politécnica, Universidade de São Paulo, USP \\ ${ }^{\mathrm{b}}$ Laboratório de Solidificação Rápida, Departamento de engenharia Mecânica, UFPB
}

Received: November 23, 2003; Revised: December 28, 2004

\begin{abstract}
The technical viability of preparing a $\mathrm{Cu}-\mathrm{Al}-\mathrm{Nb}$ shape memory alloy by high energy ball milling in a planetary mill has been evaluated. The alloy $\mathrm{Cu}-13 \mathrm{Al}-2 \mathrm{Nb}$ (wt. (\%)) was prepared by mixing pure elemental powders. A ball-to-powder weight ratio of $6: 1$ and rotation rate of $150 \mathrm{rpm}$ in argon atmosphere were the main processing parameters. The milling time ranged from 1 to 65 hours. Changes in microstructure as a function of milling time were investigated, using X-ray diffraction analysis and scanning electron microscopy. To investigate the viability of producing sintered parts from milled powders, the conventional powder metallurgy route was used. The milled powders were compacted in a cylindrical die at $900 \mathrm{MPa}$. Sintering was carried out in argon atmosphere at $850{ }^{\circ} \mathrm{C}$ for 6 hours. This study has shown that high energy ball milling, combined with pressing and sintering, can be used to promote the formation of a copper-aluminum solid solution and achieve final sintered densities of $91 \%$ of the theoretical density.
\end{abstract}

Keywords: powder metallurgy, mechanical alloying, sintering

\section{Introduction}

Shape memory alloys (SMA) are now conventional functional materials with intrinsic characteristics that differentiate them from other materials. SMA return to their original form when plastically deformed at certain temperatures above room temperature. The main characteristic of these materials with shape memory effects is diffusionless phase transformation (martensitic transformations).

In recent years, $\mathrm{Cu}$-based SMAs have been widely developed because of their relatively low cost and simpler manufacturing process, compared to Ni-Ti SMA. Among Cu-based SMAs, the $\mathrm{CuAlNb}$ system has better thermal stability ${ }^{1}$. Hence this system was selected for study. In conventional casting, alloy grain size is difficult to control. Coarse grains deteriorate the mechanical properties of the alloys. It has been reported that mechanical alloying (MA) and powder metallurgical techniques $(\mathrm{P} / \mathrm{M})$ can be used to prepare $\mathrm{Cu}$-based $\mathrm{SMAs}^{2,3}$. MA can reduce oxidation because a new phase is formed, and produces a pre-alloyed powder that shortens the sintering time. In this study, high energy planetary ball milling was used to convert the $\mathrm{Cu}-\mathrm{Al}-\mathrm{Nb}$ elemental powder mixture into pre-alloyed powders. The purpose of this investigation is to evaluate mechanical alloying as a process to obtain $\mathrm{Cu}-\mathrm{Al}-\mathrm{Nb}$ alloys with shape memory effects, with or without the addition of lubricants.

\section{Experimental Procedures}

\subsection{Preparations of pre-alloyed powders}

A planetary ball mill Fritsh Pulverisette ${ }^{\circledR}$ with four stainless steel vials was used in the MA process. Each vial contained hardened steel balls with diameters of $20 \mathrm{~mm}, 10 \mathrm{~mm}$, and $5 \mathrm{~mm}$. The ball-topowder weight ratio (BRP) was $6: 1$. The average particle size and purity of the elemental powders and the composition of the mixture are shown in Table 1.

The vials sealed with O-rings were evacuated inside a glove box and argon gas injected to avoid oxidation of the powders during the milling stage.

\subsection{Cold compaction and sintering}

Compaction was carried out in a 40-ton hand-operated hydraulic press and a single-action die, $4-5 \mathrm{~mm}$ high and with bore diameter of $9.6 \mathrm{~mm}$. The die wall was lubricated with zinc stearate. The pre-alloyed powders were compacted at a pressure of (900 MPa), to form disc-shaped green compacts. The compacts were sintered in a tube furnace at $950{ }^{\circ} \mathrm{C}$ for 6 hours in protective high purity $(99.999 \%)$ argon atmosphere, and furnace cooled. The sintered compacts were solution-treated at $900{ }^{\circ} \mathrm{C}$ for one hour followed by quenching in water to room temperature.

\subsection{Techniques used to characterize the powders and compacts}

a) Density measurement: ASTM designation 311-93;

b) X-ray diffraction analysis: Siemens D5000 diffractomete using $\mathrm{CuK} \alpha$ radiation;

c) Optical microscopy: specimens were etched with $20 \%$ Nital solution;

d) Scanning electron microscopy (SEM);

e) Differential scanning calorimetry (DSC).

\section{Results and Discussion}

\subsection{Compaction pressure}

The compaction pressure was determined from the green density versus compaction pressure curve. The pressure selected was $950 \mathrm{MPa}$ and it was kept constant.

\subsection{X-ray diffraction analysis}

\subsubsection{Samples milled without a lubricant}

Figure 1 shows changes in the structure of the $\mathrm{Cu}-\mathrm{Al}-\mathrm{Nb}$ powder mixture without a lubricant, as a function of milling time.

Figure 1 shows the diffractograms of the $\mathrm{Cu}-\mathrm{Al}-\mathrm{Nb}$ alloy powder 
milled for different times. After 3 hours of milling, the positions of the $2 \theta$ peaks of $\mathrm{Cu}-\mathrm{Al}$ are the same as that of the elemental powder, indicating that no significant reaction had occurred during milling. However after 8 hours of milling, the aluminum peak height decreased indicating that a $\mathrm{Cu}(\mathrm{Al})$ solid solution had started forming. The copper peak is displaced slightly to the right, indicating an increase in the cell parameter of $\mathrm{Cu}$, due to dissolution of $\mathrm{Al}$. Upon increasing the milling time, the $\mathrm{Al}$ peaks decrease. It can be seen that after 10 hours of milling there is only one small aluminum peak. This indicates that at this stage of milling the formation of $\mathrm{Cu}(\mathrm{Al})$ solid solution is almost complete. It is also interesting to note that other small peaks emerge. These peaks marked with $\mathrm{X}$ coincide with the peaks of orthorhombic martensite $2 \mathrm{H}$, suggesting that these could be of a martensitic structure induced by deformation during the milling process ${ }^{4}$.

\subsubsection{Samples milled with a lubricant}

Figure 2 shows the diffractograms of the mixture $\mathrm{Cu}-13 \mathrm{Al}-2 \mathrm{Nb}$ with $1 \%$ (by weight) of the lubricant zinc stearate. In this case, formation of a solid solution is sluggish, compared to the alloy mixture milled without a lubricant. Even after 65 hours of milling, large $\mathrm{Al}$ peaks can be seen. The lubricant forms a protective film on the powder surface and hinders diffusion between $\mathrm{Al}$ and $\mathrm{Cu}$.

\subsubsection{Sintered sample}

The diffraction pattern in Figure 3 shows clearly the formation of an alloy between $\mathrm{Cu}$ and $\mathrm{Al}$, resulting in a mixture of a solid solution $\mathrm{Cu}(\mathrm{Al})$ and the $\gamma_{2}$ phase.

\subsubsection{Quenched sample}

Figure 4 shows the $\mathrm{X}$-ray diffractogram of $\mathrm{Cu}-13 \mathrm{Al}-2 \mathrm{Nb}$ quenched in iced water from $850{ }^{\circ} \mathrm{C}$. An interesting feature of this diffractogram are the peaks lying between $2 \theta 30$ to 50, representing martensite structures $18 \mathrm{R}$. The profile of this diffractogram is quite similar to that of molten $\mathrm{Cu}-\mathrm{Al}-\mathrm{Ni}$ SMA reported by Zhang et al. ${ }^{5}$

Table 1. Average particle size, purity of the elemental powders and composition of the mixture.

\begin{tabular}{lccc}
\hline & $\mathrm{Cu}$ & $\mathrm{Al}$ & $\mathrm{Nb}$ \\
\hline Average particle size $(\mu \mathrm{m})$ & 75 & 75 & $75 / 44$ \\
Purity $(\%)$ & 99 & 99.9 & 99.9 \\
Mixture composition $($ wt. $(\%))$ & 85.0 & 13.0 & 2.0 \\
\hline
\end{tabular}

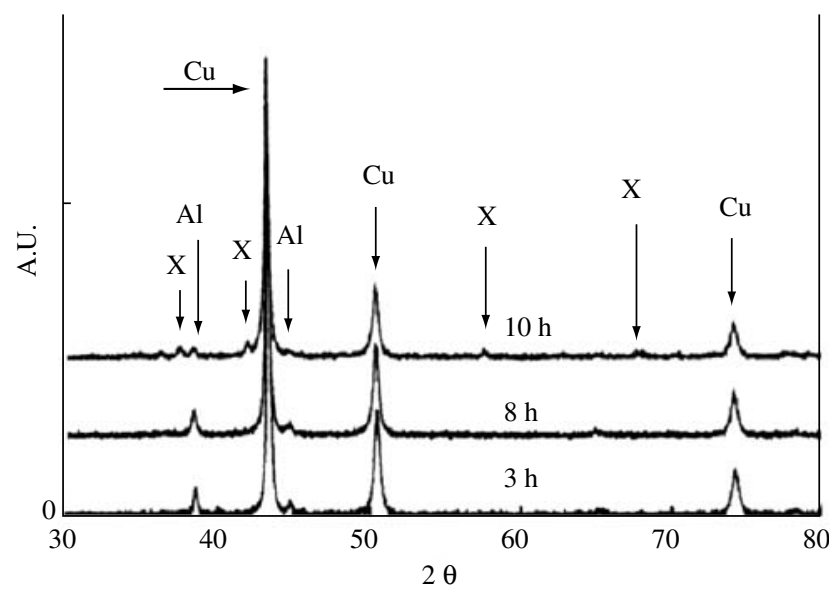

Figure 1. X-ray diffractograms of powder milled for different times at $150 \mathrm{rpm}$ without a lubricant.

\subsection{Differential scanning calorimetric analysis}

Figure 5 presents the thermogram of an annealed sample and shows clearly the two exothermic reactions in the temperature range 275 to $450{ }^{\circ} \mathrm{C}$.

The first peak has been attributed to relaxation in the microstructure, therefore the second peak is considered to be due to $\gamma$ phase formation ${ }^{4}$. There is an overlap of two heat outputs, causing inaccuracy in the determination of the temperature at which $\gamma$ phase formation begins. However, this was estimated by extrapolating the curve, and found to be $350{ }^{\circ} \mathrm{C}$. The average density of the samples without a lubricant and compacted at $950 \mathrm{MPa}$ was found to be $6.12 \mathrm{~g} / \mathrm{cm}^{3}$, which is $91 \%$ of the theoretical density of the material $\left(6.72 \mathrm{~g} / \mathrm{cm}^{3}\right)$

\subsection{Particle morphology}

The particles were examined by scanning electron microscopy. Figures 6 and 7 show particles milled for 5 and 10 hours without a lubricant. The particles are rounded and the average size is between 10-25 $\mu \mathrm{m}$.

Agglomeration of the particles can also be seen in Figure 6, indicating welding during the milling stage. Particles milled with a lubricant reveal irregular shapes and differences as a function of milling time, as shown in Figures 8 and 9. The average size of the particles depends

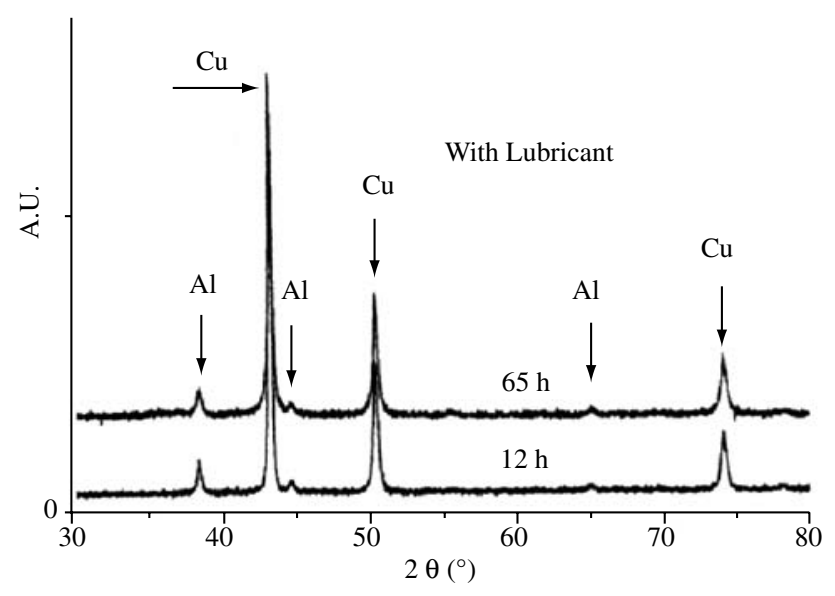

Figure 2. X-ray diffractograms of $\mathrm{Cu}-13 \mathrm{Al}-2 \mathrm{Nb}$ alloy with $1 \%$ zinc stearate milled at $150 \mathrm{rpm}$ for different times.

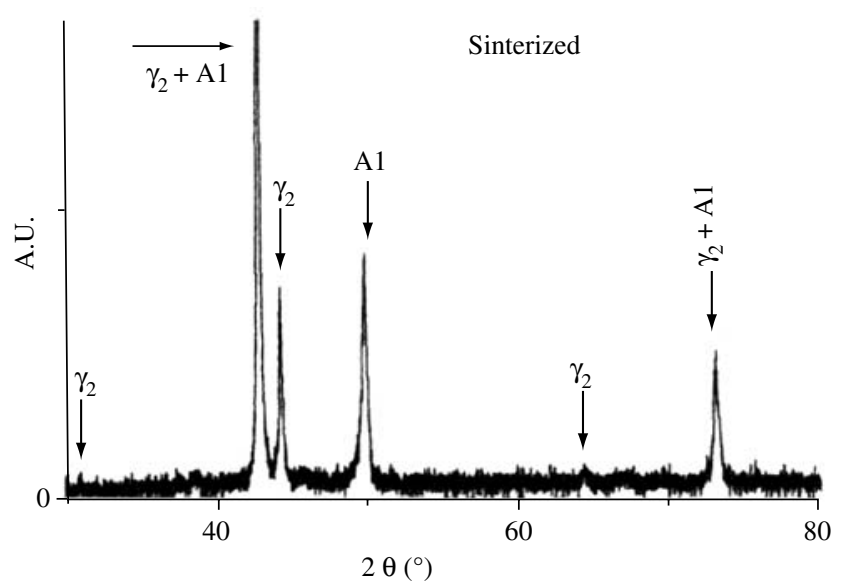

Figure 3. X-ray diffractogram of sintered $\mathrm{Cu}-13 \mathrm{Al}-2 \mathrm{Nb}$ alloy. 


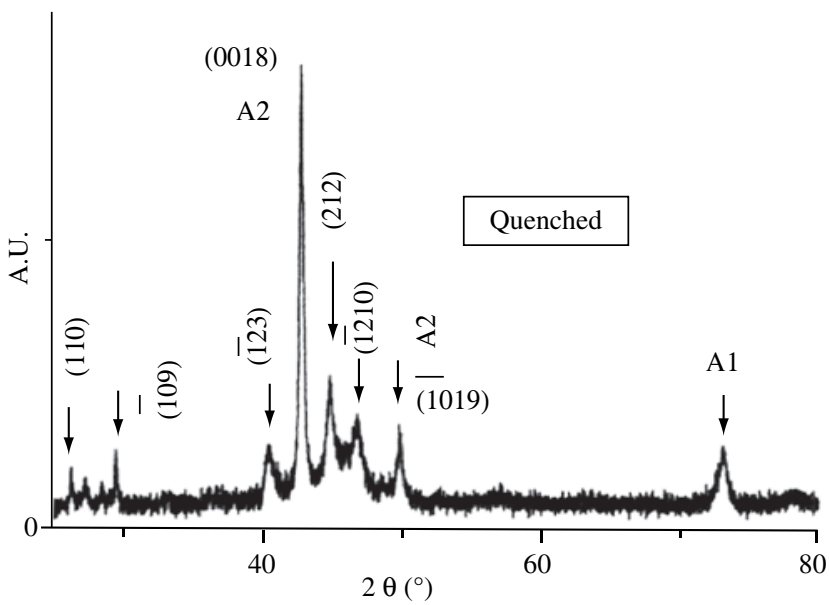

Figure 4. X-ray diffractogram of $\mathrm{Cu}-13 \mathrm{Al}-2 \mathrm{Nb}$ alloy quenched in ice water from $850^{\circ} \mathrm{C}$.

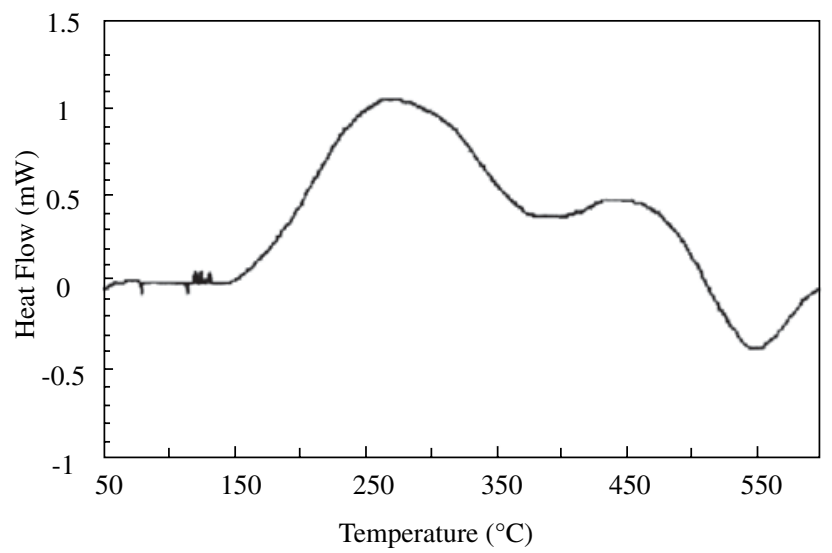

Figure 5. DSC thermogram of an annealed sample milled without a lubricant.

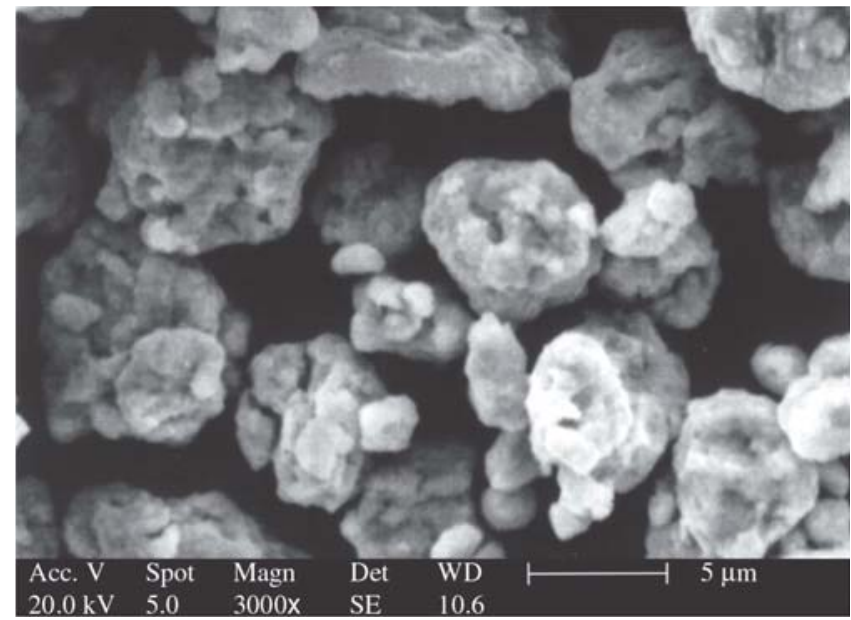

Figure 6. Scanning electron micrograph of $\mathrm{Cu}-13 \mathrm{Al}-2 \mathrm{Nb}$ milled for 5 hours without a lubricant.

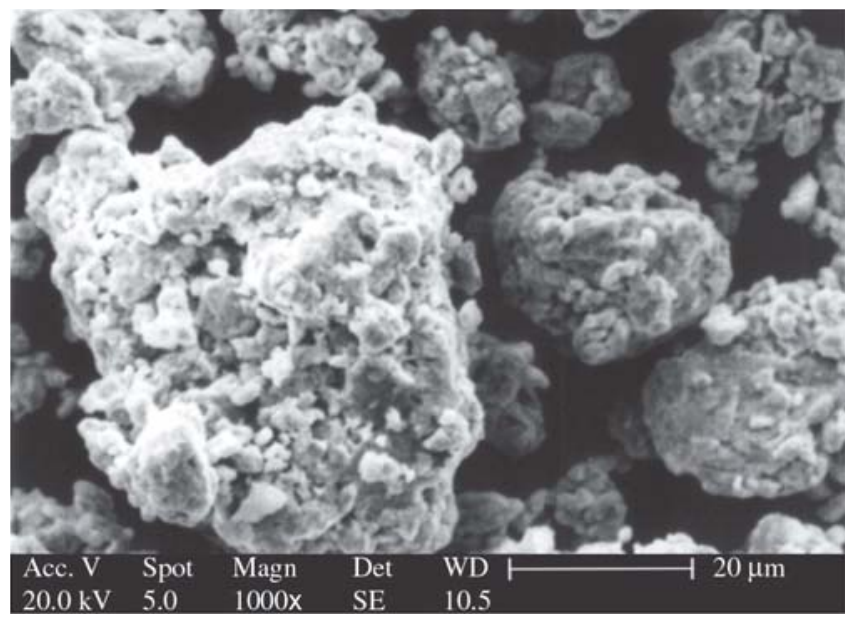

Figure 7. Scanning electron micrograph of $\mathrm{Cu}-13 \mathrm{Al}-2 \mathrm{Nb}$ milled for 12 hours without a lubricant.

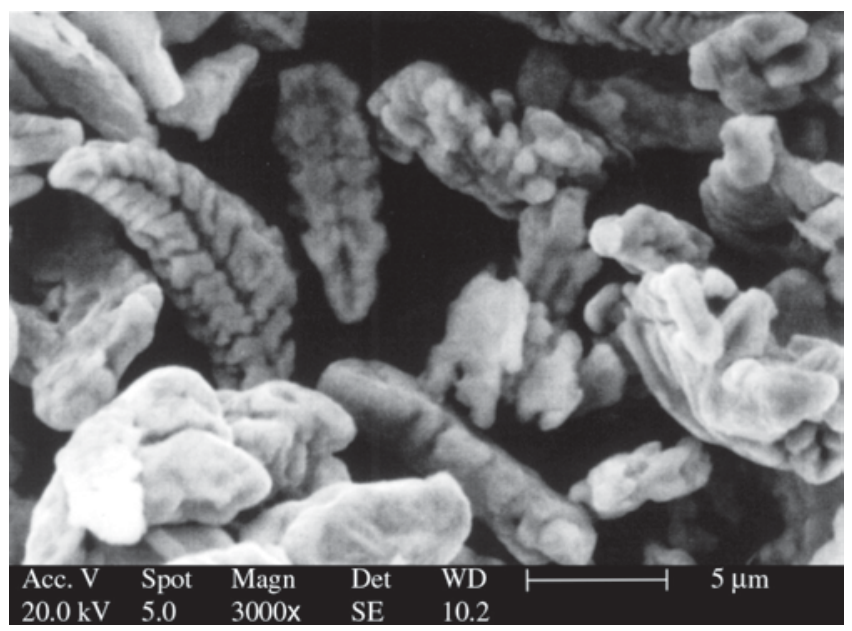

Figure 8. Scanning electron micrograph of $\mathrm{Cu}-13 \mathrm{Al}-2 \mathrm{Nb}$ milled for 12 hours with a lubricant.

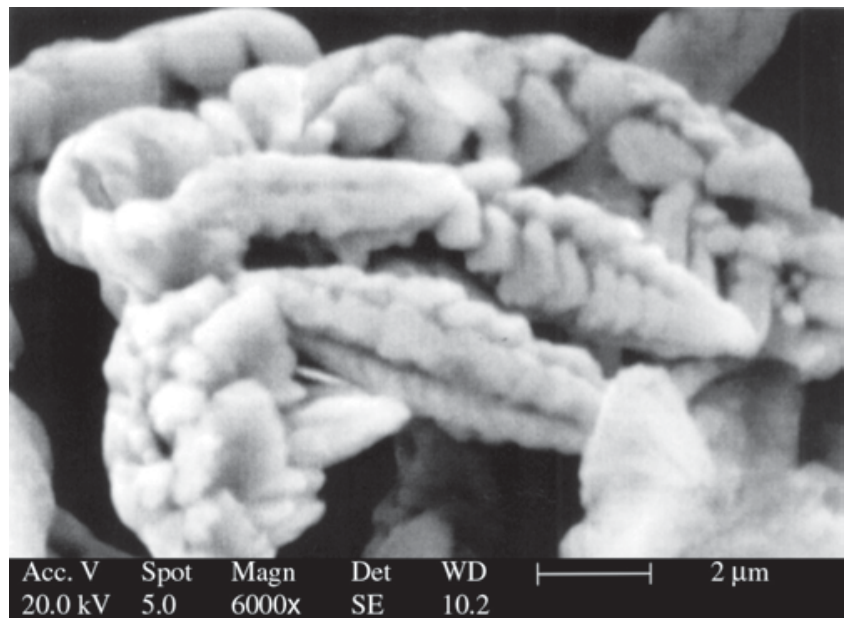

Figure 9. Scanning electron micrograph of $\mathrm{Cu}-13 \mathrm{Al}-2 \mathrm{Nb}$ milled for 12 hours with a lubricant. 
on the extent of welding and fragmentation. In the case of milling with a lubricant, the decrease in particle size is less marked.

\section{Conclusions}

- Sintering of the milled powder can only be achieved after the dissolution of aluminum in copper. Otherwise the high stability of aluminum oxide prevents diffusion;

- A solid solution of aluminum in copper can be obtained by high energy milling in a planetary ball mill;

- The lubricant has a marked influence on the mechanisms of welding and fragmentation, interfering thereby in the kinetics of alloy formation;

- Samples without a lubricant attained densities of $6.12 \mathrm{~g} / \mathrm{cm}^{3}$, representing $91 \%$ of the theoretical density;

- The martensitic 18R structure was obtained after heat treatment. This structure is essential in shape memory alloys;

\section{References}

1. Sugimoto K, Kamei K, Nakaniwa. Engineering Aspects of shape memory Alloys, T.W.Duerig editor, London: Butterworth-Heineman Ltd.; 1990. p.89-95.

2. Tang SM, Chung CY, Liu WG. Preparation of Cu-Al-Ni -based Shape Memory alloys by Mechanical alloying and Powder Metallurgy Method. Jornal of Materials Processing Technology. 1997; 63(1-3):307-312

3. Kim YD, Wayman CM. Shape Memory Effect in Powder Metallurgy NiAl Alloys. Scripta Metall. 1990; 24(2):245-250.

4. Silva MCA. Estudo da viabilidade do Uso da moagem de alta energia na obtenção da liga $\mathrm{Cu}$ - Al-Nb com memória de forma. [umpublished MSc Thesis], Federal University of Paraíba, Brazil, 2002

5. Zhang YM, Gui JN, Wang RH, Gao LM, Wu YM, Thang YL. Precipitations and its influence on the phase transition in $\mathrm{Cu}-14.1$ wt. (\%) Al4.2 wt. (\%) Ni shape memory alloy. J. Phys. Condens. Matter. 1993; 5(17):2719-2728 